Article

\title{
Certification Labels in Shaping Perception of Food Quality-Insights from Polish and Belgian Urban Consumers
}

\author{
Joanna Kaczorowska *D, Aleksandra Prandota, Krystyna Rejman *, Ewa Halicka * \\ and Agnieszka Tul-Krzyszczuk $\mathbb{D}$
}

check for

updates

Citation: Kaczorowska, J.; Prandota,

A.; Rejman, K.; Halicka, E.;

Tul-Krzyszczuk, A. Certification

Labels in Shaping Perception of Food Quality-Insights from Polish and

Belgian Urban Consumers.

Sustainability 2021, 13, 702. https://

doi.org/10.3390/su13020702

Received: 30 November 2020

Accepted: 7 January 2021

Published: 13 January 2021

Publisher's Note: MDPI stays neutral with regard to jurisdictional clai$\mathrm{ms}$ in published maps and institutional affiliations.

Copyright: $(\odot 2021$ by the authors. Licensee MDPI, Basel, Switzerland. This article is an open access article distributed under the terms and conditions of the Creative Commons Attribution (CC BY) license (https:// creativecommons.org/licenses/by/ $4.0 /)$.
Department of Food Market and Consumer Research, Institute of Human Nutrition Sciences, Warsaw University of Life Sciences WULS-SGGW, 02-776 Warsaw, Poland; aprandota@gmail.com (A.P.); agnieszka_tul_krzyszczuk@sggw.edu.pl (A.T.-K.)

* Correspondence: joanna_kaczorowska@sggw.edu.pl (J.K.); krystyna_rejman@sggw.edu.pl (K.R.); ewa_halicka@sggw.edu.pl (E.H.)

Abstract: Food quality is considered to be one of the most important determinants of food choice. Given the variety of food products and the overflow of information in the market, certification labels are intended to encourage consumers to select healthier and more sustainable product options. This study focuses on how urban consumers from Poland and Belgium perceive food quality and whether certification labels shape their views on it. Research material was collected using quantitative (Paper and Pencil Interviews (PAPI)) and qualitative (focus groups (FGs)) methods. The survey was conducted among people visiting sustainable food fairs, on a sample of 701 adults in the cities of Warsaw, Brussels and Ghent. This study confirms that consumers are interested in food quality when choosing food, but their perception varies depending on the place of residence and other socio-demographic characteristics (age, income, education, household structure). Certificates were important for consumers if their message clearly signals exceptional quality and is consistent with awareness of sustainability challenges. Consumers from Belgium (a country with a long-established market economy) reveal deeper knowledge and a more favourable approach to certification labels than Poles. The role of labelling in shaping consumers' perceptions of food quality depends on their awareness, experience and understanding of sustainability issues. This, in turn, is determined by the cultural environment of consumers, which in the case of our study was the country of residence.

Keywords: food quality; certification labels; sustainable food consumption; urban consumers; Poland; Belgium

\section{Introduction}

The quality of food products is a complex concept that has evolved over the years, depending on the scientific field in which it was analysed. There is no absolute, universal definition of food quality [1]. Initially, product quality was identified with the absence of defects or falsifications, but today it goes far beyond meeting the basic requirements and is understood as an added value of the product, distinguishing it from others in a given category. Nowadays, it can be interpreted in relation to objective parameters, which concern the product (measurable physical and chemical characteristics and the resulting properties of food), method/process and place of production, health safety/quality assurance, as well as subjective perception from the consumer's point of view [2,3]. In a subjective context, quality is defined not only by the functional needs of the consumer but also by the needs linked to the sphere of social, political, cultural, ethical or environmental relations and takes on a broader, more abstract meaning [4]. From the consumer's perspective, food quality can be seen as a set of specific attributes that a product should have in order to meet its expectations [5]. These expectations should be considered in terms of obtaining both immediate and future benefits, including the impact on health and life expectancy [6]. The perception of food quality by the consumer is a result of his 
or her previous experience, product knowledge and sensory sensitivity [7] and does not necessarily result from rational premises [8]. Differences in quality perception have many consequences in terms of consumer behaviour, beliefs and attitudes, influencing current and future purchasing decisions, eating patterns and food preparation [9]. The consequences may have a dimension of economic benefits as a result of food choices, a health dimension, both for the individual consumer and the population as a whole, and an environmental dimension, associated with the ecological footprint of selected products [10]. Some consumers perceive quality through the foodstuff's country of origin (ethnocentric attitudes), its production method or lack of preservatives and other additives. Others trust different marks and claims displayed on the packaging or look for the so-called pure labels.

The reputation of European food was severely damaged in the 1990s by numerous scandals and crisis that affected the food industry (such as bovine spongiform encephalopathyso-called "mad cow" disease, "swine flu" virus H1N1, benzene-tainted mineral water or the "chickengate" crisis related to dioxin contamination of poultry, eggs and pork). In the current decade, the European food market has been shaken by further abuses, including the E. Coli scare, the horse meat scandal, the Lactalis scandal and the fipronil-egg scandal. Moreover, some companies applied "dual quality" practices for identically-branded and similar-looking products offered on the markets of the old and new (post 2004) member states. The nature of the globalized agri-food supply chain and the economic incentive to supply cheaper food products should also be highlighted as factors that increase the possibility of food fraud. This led to reduced consumer confidence in food products from large-scale industrial production, raised concerns about food safety $[1,11]$ and prompted the development of voluntary Food Quality Assurance Schemes (FQAS) [12]. Quality or certification labels shortly become a central component of modern consumer policy in the European Union (EU) [13].

The labelling rules for food of animal origin offered on the EU market (e.g., Regulation (EU) No 1169/2011 of the European Parliament and of the Council of 25 October 2011 on the provision of food information to consumers) [14], are in principle consistent with the One Health strategy. This globally endorsed holistic approach aims to address simultaneously aspects of human health care, animal health and environmental protection in order to best manage the risks related to zoonotic diseases [15-17]. Currently, approximately $75 \%$ of newly emerging infectious diseases are zoonoses that result from various anthropogenic, genetic, ecologic, socioeconomic, and climatic factors [18]. Thus, within the framework of the EU's agricultural and food policy, further improvements to sustainability-oriented labelling were adopted in May 2020 as part of the Farm to Fork (F2F) Strategy.

In the European Union, as a part of its complex agricultural quality policy, the schemes for identifying and protecting the names of specific agricultural products and foods with unique characteristics, linked to their geographical origin as well as traditional know-how have been launched. The labels PDO (Protected Designation of Origin) and PGI (Protected Geographical Indication) represent the excellence of European agricultural food production and are both the result of a unique combination of human and environmental factors that are characteristic of a specific territory. The third label TSG (Traditional Speciality Guaranteed) highlights the traditional aspects such as the way the product is made or its composition, and protects it against falsification and misuse [19]. The granting of these certificates is governed by relevant legislation, creating specific quality standard systems that protect consumer confidence and aim to provide producers with instruments to better identify and promote products with specific characteristics and protect them against unfair market practices [20].

The internationally accepted definition of a food label "any tag, brand, mark, pictorial or other descriptive matter, written, printed, stenciled, marked, embossed or impressed on, or attached to the packaging or container of food" $[14,21]$ makes it clear how many possibilities there are to attract consumer attention. As labelling is a basic and integral part of every process of introducing a foodstuff to the market [22,23] it becomes a unique opportunity to communicate product information at the exact moment of food choice [24-27]. Therefore, in addition to the mandatory information, more and more voluntary certifica- 
tion labels covering the ethical, environmental and social aspects of production processes appear on the front of food packaging $[28,29]$. Labels on food quality in many cases signify sustainable production which protects the environment, high nutritional value and low level of processing [30]. Recent FAO (The Food and Agriculture Organization) and WHO (World Health Organization) publications point to the link between high quality foods and sustainable healthy diets which promote all dimensions of individuals' health and wellbeing, have low environmental pressure and impact, are accessible, affordable, safe and equitable, and are culturally acceptable [31]. According to WWF (World Wildlife Fund), sustainable food behaviour implies not only eating more plants, fewer foods high in fat, salt and sugar, choosing a variety of foods, wasting less food, moderating meat consumption but also buying food that meets a credible certified standard [32]. The choice of food labelled with the logo of good accreditation schemes, which are clearly defined, is among the principles of a sustainable and high quality diet [33].

These type certification labels are addressed to responsible and conscious consumers who are looking for natural, low-processed or ethical products that are suitable for their diet (e.g., plant-based diet, gluten-free, vegan) [34], for whom caring for their own and their loved ones' health is a form of intergenerational responsibility [35]. The percentage of these consumers in society is not large, albeit growing, as a result of increasing public awareness of the shared responsibility for the state of the planet that the current population will leave for future generations.

Certificates help reduce the uncertainty that arises in the process of evaluating product quality before buying [36], thereby facilitating choice and purchasing decisions. Certification schemes are used to ensure marketing claims for unobservable quality attributes. Under asymmetric information, process-oriented quality characteristics such as organic farming, animal welfare, or fair trade raise the question of mislabeling [37]. From the manufacturer's point of view, certificates are a tool of nutritional marketing and competitive struggle, even if their acquisition is dictated by concern for sustainable development and is embedded in the company's mission of being a responsible manufacturer. More and more companies understand the imperative to prove their social and environmental commitment as the number of consumers who are aware of the social and environmental impact of their purchasing decisions grows [38,39]. The Ipsos report [40] identifies more than 900 food labelling schemes used in the EU Member States, Iceland and Norway. Worldwide the largest eco-labelling catalogue [41] describes 456 labelling schemes available in 199 countries, 148 of which relate to organic food. Food producers use these various opportunities to attract consumer attention, but research shows that food buyers are overwhelmed by the amount of information on labels and there is some kind of immunisation to the perception of certificates $[29,42,43]$. The proliferation of certification labels contributed to generate consumer doubts and confusion, especially if they do not have much knowledge about the certificates, who awards them and on what terms and if they are trustworthy, there can be a "label fatigue" effect [13,44-46].

In this context, some authors point to a common refrain in research on the role of certification labels due to their great number and diversity [46]. Others, on the contrary, argue that there is still a need to deepen the investigation on the extent to which quality labels are important to consumers and if they are perceived as a guarantee of product safety and/or quality [13]. We share the latter approach, especially in the context of the commitment to the 17 global sustainable development goals and the New Green Deal strategy in the EU.

With this in mind, the aim of this paper was to understand how consumers from two EU countries with different cultural and economic backgrounds-Poland and Belgiumperceive food quality and determine if certification labels shape their views on this issue. After the change of the economic system and the adoption of a strategy for the development of a democratic state, Poland became a member of the EU in 2004, while Belgium was one of the founding states of the European Economic Community (former name of the EU). Poland represents a country with a young market economy, while Belgium is a country 
with a mature market. The purchasing behaviour of Polish consumers differs from that of the Belgian ones as it is deeply rooted in the culture of both nations. The development and structure of the food retail market also influences different purchasing behaviours. In 2017, households in Belgium and Poland spent $13.4 \%$ and $16.8 \%$ of their total consumption, respectively, on food and non-alcoholic beverages [47]. These percentages indicate that economic determinants play a greater role in the purchase decisions of Poles. In Poland, the leaders in retail sales are two discount store chains. Biedronka (of Portuguese Jeronimo Martins Group) is the dominant chain with the largest number of stores with over 3000 outlets in 2020. Its revenues are three times higher than those of Lidl (second place, owned by the German Schwarz Group), which also has almost three times fewer outlets [48]. Polish consumers are convinced of the high quality of local food, therefore a significant part of retail sales, especially of fruit and vegetables, takes place at markets and bazaars. In 2019 there were almost 2160 permanent and 7100 seasonal market places in the country [49]. In Belgium, the French chain Carrefour continues to be the leader in retail sales and is developing with new store concepts. The grocery retail market in Poland is characterized by higher growth dynamics (4.4\% in 2017-2019), than in Belgium (3.4\% in 2014-2018) [50,51]. In terms of qualitative development of the food retail market, the opposite is true-Belgium is ahead of Poland. In Belgian proximity, premiumisation, comfort and convenience are the driving forces of change [52], while in Poland, proximity and convenience are emerging trends. Hypermarkets lose out to smaller formats, independent stores joining franchise chains are gaining importance, but also forecourt retailers benefit from the ability to trade on Sundays [53]. It should be emphasized that both leading discount chains in Poland are building their competitive advantage by offering an increasing choice of products with European PDO, PGI and TSG quality certificates.

To minimise the possible influence of the differences in the level of the social and economic standing of both studied communities, the research was conducted in the urban and most developed regions of Poland and Belgium.

\section{Materials and Methods}

\subsection{Data Collection}

In order to obtain an in-depth understanding of the studied issues, two different methods of primary data collection were used. To begin with, quantitative data were gathered with the use of the Paper and Pencil Interviews (PAPI) method, via the direct interview face-to-face technique. The structured interview questionnaire was pre-tested on a group of 15 consumers and revised before data collection. The final version of the questionnaire consisted of 28 substantive and 7 metric questions and was prepared in four language versions: in Polish for the respondents from Warsaw and in English, French and Dutch for those living in Belgium.

The surveys were conducted during local community events aimed at promoting sustainable food (locally produced, seasonal, artisanal, organic, certified etc.) in Warsaw, Brussels and Ghent, i.e., a university city near Brussels. These events included: Piknik Poznaj Dobrą Żywność (Picnic Get to Know Fine Food), Międzynarodowy Jarmark Produktów Tradycyjnych i Regionalnych (International Fair of Traditional and Regional Food Products) in Warsaw, Urban BBQ, piQniQ in Brussels and a Gent Smaakt (Tastes of Ghent) Festival. Data were gathered by 11 interviewers, 5 in Poland and 6 in Belgium. Each interviewer had been familiarized with the aims and assumptions of the survey, the construction of the questionnaire and was trained in the scope of conducting the interviews. The average interview time was 20-25 min.

The second stage of data collection was designed to provide a deeper understanding of the studied phenomena linked to food certification. The focus groups (FGs or group interviews) method was chosen as a popular and effective technique to collect qualitative data [54]. The method is based on several scheduled and moderated group interviews with 6-8 participants. During FGs, participants interact, share individual experiences, opinions and attitudes what illuminates the variety of viewpoints held in a study population [55]. 
The interview scenario used in the study was planned and pre-tested to maximize the collection of high-quality data, as well as to make sure that the interviews did not last longer than $2 \mathrm{~h}$. Pilot qualitative research was carried out in a group of 5 people (women and men aged 28 to 55 years) and led to the introduction of minor adjustments of the final version of the interview scenario. All group interviews in Warsaw and Brussels were moderated by the same person - the second author of this article. In Poland, the language of group discussion was Polish and in Belgium-English. The FGs lasted for 90-120 min.

\subsection{Sample}

The total research sample consisted of 701 urban residents, of which 359 were from Warsaw, 308 from Brussels and 34 from Ghent.

In order to select individuals, the non-probability purposive sampling method was applied. This was due to the fact that the level of recognition and understanding of sustainability labels among the population is generally low [56-58]. That led to the conclusion that the research should be conducted among people who professionally or for personal reasons, show interest in sustainable food products, which in accordance with EU food quality policy include certified food products. Moreover, statistical data for Poland and Belgium confirms that residents of larger cities tend to have better education and income. The food market infrastructure in such cities is also better than in less urbanised areas and a larger stream of marketing activities is directed to food buyers. Therefore, inhabitants of large cities may be more interested in sustainability issues and familiar with sustainable food labelling.

Altogether 330 people from Poland and 329 from Belgium took part in the quantitative survey. Despite the fact that all data were collected anonymously, extra care was taken to ensure that the share of women and men was similar in both countries. The sociodemographic questions in the survey concerned the respondent's gender, age, level of education, type of employment, the household's size and its average monthly income (per person) as well as a subjective assessment of its financial situation Respondents were also asked if they were the primary food shopper in their household (Table 1).

Table 1. Sociodemographic characteristics of the quantitative study sample.

\begin{tabular}{|c|c|c|c|c|c|}
\hline \multicolumn{3}{|c|}{ Variable } & $\begin{array}{c}\text { Total Sample }(\%) \\
n=659\end{array}$ & $\begin{array}{c}\text { Poland }(\%) \\
n=330\end{array}$ & $\begin{array}{c}\text { Belgium }(\%) \\
n=329\end{array}$ \\
\hline \multirow{2}{*}{ Gender } & \multirow{2}{*}{\multicolumn{2}{|c|}{$\begin{array}{c}\text { Male } \\
\text { Female }\end{array}$}} & 36.9 & 38.9 & 35.0 \\
\hline & & & 63.1 & 61.1 & 65.0 \\
\hline & \multicolumn{2}{|c|}{ Below 25} & 22.2 & 29.9 & 16.7 \\
\hline & \multicolumn{2}{|c|}{$26-35$} & 33.7 & 19.3 & 37.6 \\
\hline Age (years) & \multicolumn{2}{|c|}{$36-45$} & 19.0 & 12.5 & 18.6 \\
\hline & \multicolumn{2}{|c|}{$46-55$} & 12.6 & 10.9 & 12.8 \\
\hline & \multicolumn{2}{|c|}{ Over 55} & 12.6 & 27.4 & 14.3 \\
\hline \multirow{3}{*}{ Education } & \multicolumn{2}{|c|}{ Primary or vocational } & 6.7 & 5.4 & 7.9 \\
\hline & \multicolumn{2}{|c|}{ Secondary } & 35.2 & 19.2 & 18.1 \\
\hline & \multicolumn{2}{|c|}{ Higher (BSc, MSc or higher) } & 58.1 & 75.4 & 74.0 \\
\hline \multirow{4}{*}{$\begin{array}{l}\text { Household size } \\
\text { (number of people) }\end{array}$} & \multicolumn{2}{|c|}{1} & 19.6 & 13.1 & 26.4 \\
\hline & \multicolumn{2}{|c|}{2} & 33.9 & 29.4 & 38.6 \\
\hline & \multicolumn{2}{|c|}{3} & 18.3 & 21.3 & 15.2 \\
\hline & \multicolumn{2}{|c|}{4 and more } & 28.3 & 36.2 & 19.8 \\
\hline \multirow{7}{*}{$\begin{array}{l}\text { Household average } \\
\text { monthly income * } \\
\text { (per person) }\end{array}$} & PLN & EUR & & & \\
\hline & $<1000$ & - & 4.2 & 8.4 & - \\
\hline & $1001-1500$ & $<1500$ & 22.7 & 17.9 & 28.0 \\
\hline & $1501-2000$ & $1501-2500$ & 30.8 & 17.6 & 45.3 \\
\hline & 2001-3000 & $2501-3000$ & 19.1 & 23.2 & 14.5 \\
\hline & $3001-4000$ & $3501-4500$ & 9.7 & 12.2 & 6.9 \\
\hline & $>4000$ & $>4500$ & 13.3 & 20.7 & 5.3 \\
\hline
\end{tabular}


Table 1. Cont.

\begin{tabular}{|c|c|c|c|c|}
\hline Variable & & $\begin{array}{l}\text { Total Sample }(\%) \\
\qquad n=659\end{array}$ & $\begin{array}{l}\text { Poland (\%) } \\
\quad n=330\end{array}$ & $\begin{array}{c}\text { Belgium (\%) } \\
\quad n=329\end{array}$ \\
\hline \multirow{5}{*}{$\begin{array}{l}\text { Household financial situation } \\
\text { (subjective assessment) }\end{array}$} & Very good & 12.5 & 13.5 & 11.5 \\
\hline & Rather good & 42.7 & 40.8 & 44.8 \\
\hline & Average & 37.9 & 39.6 & 36.1 \\
\hline & Rather bad & 5.2 & 4.9 & 5.4 \\
\hline & Very bad & 1.7 & 1.2 & 2.2 \\
\hline \multirow{2}{*}{ The respondent is the primary food shopper } & Yes & 77.3 & 74.7 & 80.2 \\
\hline & No & 22.7 & 25.3 & 19.8 \\
\hline
\end{tabular}

* Clearly considerable differences in the nominal income levels of the groups of respondents must be considered in the context of average wages in both countries and taking into account different currencies (PLN and EUR)

The group interviews were conducted among 42 consumers, of which 29 lived in Warsaw and 13 in Brussels. The selection process utilized the purposive sampling approach and was based on the results of the quantitative research. Gender was selected as the criterion for differentiating the groups. Altogether 6 focus groups ( 3 male and 3 female) were carried out with a total of 20 women and 22 men. In Poland out of the total four FGs two consisted of women and two of men. The first group of Polish women (pw1) involved 6 participants, the second (pw2) 8. Among Polish men, the first group (pm1) numbered 7 individuals and the second 8 (pm2). One FG conducted in Belgium was made up of 6 women (bw), the other FG of 7 men (bm). The respondents represented different professional groups, income and education levels. Almost all FGs were dominated by people with higher education with the exception of the Belgian group of men, who mostly declared lower education levels and working as labourers.

\subsection{Methods}

Quantitative data were collected using a structured interview questionnaire, divided into 7 thematic blocks on consumer purchasing behaviour, perception of food quality and high-quality food and attitudes towards food with certification labels. For the purpose of this article, only part of these questions was used (Appendix A). In order to determine the importance of quality in food selection, a 5-point Likert scale was used, where 1 indicated "definitely no", 2-"rather no", 3-"no opinion", 4-"rather yes" and 5-"definitely yes". For the assessment of the quality of food produced in a given country, a discrete 5-point ascending scale was used, where 1 meant "very low", 2-"low", 3-"average", 4-"high" and 5-"very high". In the question devoted to the features distinguishing food products of high quality, respondents expressed their opinion on 16 factors, that were previously selected in the literature review. Opinions were measured on a 5-point Likert scale, where 1 indicated "strongly disagree", 2-"rather disagree", 3-" "neither yes nor no", 4-" rather agree" and 5-"strongly agree". The part of the questionnaire concerning attitudes towards food with certification labels consisted of closed-ended questions with non-imposing character. Respondents could choose among 3 answers: "yes", "no" or "I am not able to tell". This was due to limited awareness and recognition of product labels. Additionally, the importance of certification labels on the packaging for consumers when they choose food products was measured on a discrete 5-point ascending scale with the end values anchored as 1-“least important" and 5- "most important".

Qualitative data were gathered during focus group interviews according to the interview scenario, which consisted of 5 thematic blocks. In order to meet the research objectives of this paper, only part of the gathered material concerning the importance of food quality for consumers and the role of quality certificates was used. Participants were asked how they recognize the high quality of food products, whether it is important to them when shopping and what the certification labels on food products really mean and whether they matter to them. During the interviews, various stimuli for discussion were used, 
including graphic mock-ups of certification labels operating on the Belgian and Polish markets, respectively.

\subsection{Data Analysis}

The quantitative data analysis was performed in the SAS ${ }^{\circledR}$ system 9.3 (SAS Institute Inc., 2013, Cary, North Carolina, NC, USA) and Statistical Package for Social Sciences (IBM SPSS Statistics version 25, SPSS Inc., Chicago, Illinois, IL, USA). At first, data were investigated through descriptive statistics (frequency, means and cross-tabulations). For the correlation analysis the Pearson's non-parametric chi-square test was used and for the comparative analysis-Kruskal-Wallis' test. The nominal variables were compared using Pearson's chi-square test. For orderly variables (age and number of people per household), a non-parametric Mann-Whitney's test was applied. A level of $p \leq 0.05$ was considered as significant. To interpret the associations between variables V-Cramer's test was used.

Subsequently, Factor Analysis was employed to carry out simultaneous analysis of the information provided by a large number of variables on how consumers perceive high-quality food products. Factor Analysis was performed through Principal Component Analysis (PCA) method and followed by a Varimax rotation with Kaiser normalization [59]. Factor extraction was based on the criterion eigenvalue greater than one and confirmed by the Scree Plot. As a result, four components (factors) explaining $55.40 \%$ of the original variance were identified (Table 2 ). All extracted components had good internal reliability consistency measured through the Cronbach's alpha $(\alpha>0.7)$.

Table 2. Component Matrix (Principal Component Analysis (PCA), Varimax Rotation Method—Kaiser Normalisation).

\begin{tabular}{|c|c|c|c|c|c|}
\hline \multirow{2}{*}{ Attributes } & \multirow{2}{*}{ Product Features } & \multicolumn{4}{|c|}{ Component (\% of Variance) } \\
\hline & & 1st (17.3) & 2nd (17.0) & 3rd (10.7) & 4th (10.5) \\
\hline \multirow{5}{*}{ Sustainability } & $\begin{array}{l}\text { No/very low amount of additives, i.e., colorants, } \\
\text { preservatives, enhancers }\end{array}$ & 0.706 & -0.074 & 0.062 & 0.011 \\
\hline & Beneficial effect on health & 0.665 & -0.009 & 0.164 & 0.099 \\
\hline & Ingredients of known and controlled origin & 0.640 & -0.073 & 0.308 & -0.019 \\
\hline & Minimal level of processing & 0.630 & 0.113 & 0.072 & -0.093 \\
\hline & Ethical production & 0.629 & 0.111 & -0.142 & -0.024 \\
\hline \multirow{6}{*}{ Marketing } & Extensive advertising and promotion & -0.107 & 0.750 & -0.115 & 0.241 \\
\hline & High price & -0.217 & 0.678 & 0.025 & 0.005 \\
\hline & $\begin{array}{l}\text { Indication, symbol or certificate on the packaging that other } \\
\text { products do not have }\end{array}$ & 0.207 & 0.658 & 0.176 & -0.072 \\
\hline & Awards, distinctions, medals obtained & -0.031 & 0.633 & 0.266 & -0.012 \\
\hline & Esthetical / attractive packaging & -0.104 & 0.594 & 0.062 & 0.462 \\
\hline & Sales in reputable places & 0.209 & 0.575 & -0.030 & 0.027 \\
\hline \multirow{3}{*}{ Technological } & Special recipe & 0.140 & 0.111 & 0.822 & 0.155 \\
\hline & Special production method or with use of special technology & 0.180 & 0.153 & 0.789 & -0.019 \\
\hline & High quality of ingredients & 0.359 & -0.184 & 0.577 & 0.195 \\
\hline \multirow{2}{*}{ Sensory } & Attractive appearance & -0.156 & 0.254 & 0.097 & 0.820 \\
\hline & Good taste and smell & 0.224 & -0.070 & 0.042 & 0.803 \\
\hline
\end{tabular}

Although "sustainability" product attributes explained the biggest share $(17.3 \%)$ of the variance, "marketing" features, incl. indications, symbols or certificates displayed on the packaging followed close behind and accounted for $17.0 \%$. The remaining two groups of product attributes, classified as "technological" and "sensory" explained 10.7\% and $10.5 \%$ of the variance, accordingly. 
The qualitative data analysis involved recording transcription, coding (data categorisation to make it easier to interpret) and interpreting. The data acquired through the interviews was encoded using an Excel spreadsheet (Microsoft).

\section{Results}

\subsection{Quality as a Food Choice Determinant}

According to study participants, the quality of products was an important factor influencing their food choices. In the quantitative part of the study the vast majority of respondents (93.5\%) admitted that "yes" they "definitely" or "rather" take it into account when shopping. In general, the structure of responses in Polish and Belgian consumers did not differ significantly and the dominant answer ("definitely yes") was given by $57.8 \%$ and $47.9 \%$, respectively. The opposite views ("definitely no" or "rather no") were indicated only by $3.9 \%$ of Polish respondents and $5.8 \%$ of the Belgian ones.

Among Poles the quality of food products was more important for respondents from larger (two- and three-person) households $(p=0.0185, v=0.1783$ ), those who assessed their financial situation as "very good" and "rather good" $(p=0.0352, v=0.1457)$ or were highly educated ( $p=0.0020, v=0.683$ ). Statistically significant relationships were found between food quality importance and age among both Polish $(p=0.0480, v=0.1438)$ and Belgian consumers $(p=0.0026, v=0.1725)$. The results also show that with age more respondents declared definitely taking the quality of food products into account when shopping.

FG participants also confirmed that quality is an important factor in the food selection process. Nevertheless, the discussions showed that consumers never take food quality into account by itself. Most often quality is considered in relation to price i.e., "if the quality of meat is good and the price acceptable then I will buy the quality product, but if it is too high then I will choose another one" (bm). Polish men paid the least amount of attention to the quality of the food product and it was noted by the FG moderator that these opinions came usually from younger consumers. On the other hand, quality as a food choice determinant was most important for Belgian women, for example: "I have a long list of criteria. The first one is quality, second is the budget that I have available and third the origin of the product. I have a certain scale in my head and I make an analysis" (bw).

In the subsequent part of quantitative research, participants were asked whether they were willing to pay more for products that meet higher quality standards. Most of them $(67.1 \%)$ "rather agreed" or "definitely agreed". However circa $16 \%$ of respondents "rather disagreed" or "definitely disagreed" to pay more. Consumers from both countries expressed similar opinions.

The willingness to pay a higher price for high quality products was significantly correlated with a positive assessment of the financial status of the household (Polish group $p=0.0422, v=0.1444$; Belgian group $p=0.0003, v=0.1888$ ). Among Belgian consumers, declarations were also linked to the age of respondents $(p=0.0019, v=0.1786)$. The older the respondents, the more often they agreed to pay a higher price. During the focus group interviews, consumers usually affirmed their willingness to pay a higher price, for example: "when it comes to the basic food products such as for example bread, I am willing to pay even 100\% more for higher quality" (pm2). Interestingly, the willingness to pay a higher price for higher quality was seen as being, associated with a particular way of producing food, i.e., "Young people are willing to spend more on products of higher quality, e.g., artisanal beer (... ). Jertheless, some Polish interviewees openly admitted that their income does not allow them to buy high-quality food for all household members due to its high price i.e., "we buy better quality food, but mainly for our daughter" (pm1).

More than half of the Polish and Belgian respondents shared the opinion that the quality of food produced in their country is "high" (56.4\% and $46.0 \%$, respectively) or "very high" (9.8\% in both countries). On the other hand, according to one-third of the respondents, food produced in their countries is of "average quality" (31.0\% of Poles and $39.7 \%$ of Belgians). However, no statistically significant differences in the structure of responses of Polish and Belgian consumers were found. Only in the Polish group, socio- 
demographic characteristics of the respondents differentiated the assessment of the quality of domestic food. These were the financial situation of the household $(p=0.0237, v=0.1501)$ and the age of the respondents $(p=0.0377, v=0.1469)$. The better the respondents perceived their financial situation or the older they were, the more often their assessment of the quality of Polish food was positive.

All interviewees who participated in the qualitative part of the survey agreed that food produced in their countries is of high quality. Nevertheless, many statements indicated that the availability of this food was often limited by their financial resources e.g., "there is a lot of quality food on the Belgian market, but its availability to me depends on my budget" (bm). In Poland, both male and female groups were more likely to admit that domestic food is of better quality e.g., "according to experts' opinions, nowadays, ( . . ) we have poor food quality. (...) I have confidence in Polish food in comparison to what is generally available in Europe" (pw2) or "Polish food is better in general due to lower levels of chemical usage in agriculture compared to Western European countries ( . . . )" (pm2). Remarkably, FGs in both countries stressed that some products may be of better quality when imported or purchased abroad: "in my opinion for example fish is better in France than in Belgium, depending on the product" (bm). In Poland special attention was additionally drawn to the problem of "dual food quality": "foreign brands produce food of lower quality for the Polish market than for other foreign markets" (pw1).

\subsection{Perception of Food Quality}

According to survey participants, food quality is itself very complex, and consumers, when evaluating it, take into consideration different product characteristics simultaneously. The results of the quantitative part of the study showed that the desired sensory characteristics (i.e., good taste and smell as well as attractive appearance) most often convinced respondents that the product is of high quality (Table 3). The average score for this group of determinants was 3.91 in the total sample (on a scale from one to five), but Belgian respondents rated them statistically significantly lower (mean 3.76) than Poles (4.06).

Table 3. The mean scores of selected features that distinguish high-quality food products, measured on a 5-point Likert scale from 1-"strongly disagree" to 5-"strongly agree".

\begin{tabular}{|c|c|c|c|}
\hline Attributes & Total Sample & Poland & Belgium \\
\hline I. Sensory & 3.91 & $4.06^{\mathrm{a}}$ & $3.76^{\mathrm{b}}$ \\
\hline Good taste and smell & 4.17 & $4.29^{\mathrm{a}}$ & $4.05^{b}$ \\
\hline Attractive appearance & 3.64 & $3.82^{\mathrm{a}}$ & $3.46^{\mathrm{b}}$ \\
\hline II.Sustainability & 3.76 & 3.81 & 3.71 \\
\hline Beneficial effect on health & 3.99 & 4.06 & 3.92 \\
\hline No/very low amount of additives, e.g., colorants, preservatives, enhancers & 3.97 & $4.10^{\mathrm{a}}$ & $3.83^{b}$ \\
\hline Ingredients of known and controlled origin & 3.86 & 3.87 & 3.83 \\
\hline Minimal level of processing & 3.54 & $3.65^{\mathrm{a}}$ & $3.42^{b}$ \\
\hline Ethical production & 3.43 & $3.36^{\mathrm{b}}$ & $3.51^{\mathrm{a}}$ \\
\hline III. Technological & 3.67 & 3.77 & 3.56 \\
\hline High quality of ingredients & 4.26 & 4.27 & 4.24 \\
\hline Special production method or with use of special technology & 3.41 & 3.49 & 3.32 \\
\hline Special recipe & 3.34 & $3.55^{\mathrm{a}}$ & $3.11^{\mathrm{b}}$ \\
\hline IV. Marketing & 2.81 & $2.93^{\mathrm{a}}$ & $2.68^{\mathrm{b}}$ \\
\hline Awards, distinctions, medals obtained & 3.07 & $3.20^{\mathrm{a}}$ & $2.93^{b}$ \\
\hline Sales in reputable places & 3.05 & $2.95^{b}$ & $3.14^{\mathrm{a}}$ \\
\hline Indication, symbol or certificate on the packaging that other products do not have & 2.92 & $3.03^{\mathrm{a}}$ & $2.82^{b}$ \\
\hline High price & 2.76 & $2.87^{\mathrm{a}}$ & $2.64^{\mathrm{b}}$ \\
\hline Esthetical/attractive packaging & 2.73 & $3.04^{\mathrm{a}}$ & $2.41^{\mathrm{b}}$ \\
\hline Extensive advertising and promotion & 2.32 & $2.51^{\mathrm{a}}$ & $2.14^{\mathrm{b}}$ \\
\hline
\end{tabular}

* Superscript letters "a" and " $b$ " indicate whether the groups of respondents differ significantly in the evaluation of a given product attribute $(p \leq 0.05)$. 
From the consumers' point of view, also sustainability attributes (beneficial effect on health, known origin and low degree of processing) indicate high food quality. The average score for the five determinants in this group was 3.76. The most important among them was "beneficial effect on health", where the mean in the total sample equalled 3.99 and no significant differences in its assessment were observed between Polish and Belgian respondents. The means of the remaining four features assessed by all study participants ranged from 3.97 ("no/very low amount of additives, e.g., colorants, preservatives, enhancers") to 3.43 ("ethical production"). In general, Belgians rated the importance of these attributes lower than Poles, except for "ethical production", which obtained a statistically significantly higher mean.

In the Polish group, statistical relationships were found between the evaluation of product features linked to sustainability and respondents' age $(p=0.0263, v=0.1521)$, education level ( $p=0.0231, v=0.1491)$ and subjective assessment of the household's financial situation $(p=0.0043, v=0.1769)$. They were rated higher by respondents aged 36 years+, holders of higher education and those who assessed their financial situation as "average" or "rather good". Among Belgians, no statistically important relationships were observed.

The group called "technological attributes" (3.67 on average in the total sample) was slightly less important in characterizing high-quality food. The most significant feature"high quality of ingredients" — was highly rated in the total sample (4.26) as well as in both respondent groups. The least important feature in this group was "special recipe", rated lowest by Belgian respondents (3.11). Polish respondents who accessed their financial situation as "rather good" or "rather bad" assigned more weight to this set of characteristics, when assessing product quality ( $p=0.0198, v=0.1593)$.

The collected quantitative data pointed out that consumers saw the importance of marketing attributes as minor in distinguishing high-quality food products. Most of the respondents' indications were between two-" "rather disagree" to three-"neither yes or no". Among this set of features, the highest average was obtained by "awards, distinctions, medals" (mean score in total sample 3.07). The least convincing feature that the product is of high quality is its "extensive advertising and promotion" (2.32). Statistically significant differences were observed in the assessment of all attributes from this set among Polish and Belgian consumers. In general, Poles assessed the importance of marketing attributes higher than Belgians, with the exception of "selling in reputable places" where the average score of the Belgian group was 3.14 and the Polish 2.95. The financial situation was the only sociodemographic characteristic that statistically differentiated the respondents' assessments (for Polish respondents $p=0.000, v=0.1985$, for Belgians $p=0.004, v=0.1739$ ). Consumers who assessed their financial situation as "average" or "rather good" indicated that the marketing attributes were more meaningful in distinguishing high-quality food products.

The results of the FGs also revealed that high-quality food products were most often understood and defined as tasty, fresh, and natural, of a low degree of processing and with an expected composition (Table 4). The interviewees also paid a lot of attention to the health aspects of high-quality products that improve wellbeing, promote health and can be useful in the prevention of diseases. Other features of high-quality food were also named and included place of origin, production methods and marketing attributes like packaging, label or brand. 
Table 4. Comments made by the focus group (FG)'s participants on the features of high-quality food.

\begin{tabular}{|c|c|}
\hline FG & Statements \\
\hline & Sensory attributes \\
\hline pw2 & A higher quality product tastes better; \\
\hline pm2 & A quality product is a fresh, natural product; \\
\hline pw1 & A quality product for me is the least processed product (...), fresh; Quality food is something fresh, safety proofed \\
\hline bw & Quality (...) is for me freshness and then taste; \\
\hline \multirow[t]{2}{*}{ bm } & If it tastes good it's of high quality; \\
\hline & Health aspects \\
\hline pw1 & $\begin{array}{l}\text { I understand quality in two dimensions: in the sense of what diet I choose, meaning healthier or less healthy, and within this } \\
\text { diet I can choose products from a better or worse producer; Food can be a remedy, I have a cosmetology education, what we eat } \\
\text { has a very big influence on e.g., the appearance of the skin; }\end{array}$ \\
\hline bw & $\begin{array}{l}\text { When I go to the doctor, now that I have health problems, the first question they ask me is if I'm on a diet, because they } \\
\text { immediately think it has a big impact on our health; } \\
\text { Place of origin }\end{array}$ \\
\hline bw & For me, the place of origin of a product is a part of quality; \\
\hline pw2 & It is important where it comes from, e.g., butter should be only from Grajewo, with a clover*; \\
\hline \multirow[t]{2}{*}{ pw1 } & The quality of feed for hens certainly translates into the quality of eggs; \\
\hline & Production and processing methods \\
\hline pm2 & $\begin{array}{l}\text { Quality is affected by the way in which food is preserved and processed;The type of slaughtering affects the quality of the meat, } \\
\text { as blood and other fluids decompose most rapidly; }\end{array}$ \\
\hline pw1 & $\begin{array}{l}\text { I would say that the quality of food depends on how it is produced, how much or not it has been 'sprayed' with pesticides, for } \\
\text { example; }\end{array}$ \\
\hline pw2 & Lately, I have not been buying cold cuts at all (...) because we know that there are chemicals in it, which hurt us; \\
\hline & Marketing attributes: packaging, label, brand \\
\hline $\mathrm{bm}$ & $\begin{array}{l}\text { The products of the Dutch company HAK, although they are canned, are always in glass packaging, this is part of their } \\
\text { marketing, at least you can see what is inside. This is, in my opinion, an element of the quality of this productWhen I look for } \\
\text { high quality, I read the label on the packaging (...), sometimes it is written e.g., category one, as in the case of meat, and } \\
\text { sometimes that it is restaurant quality; }\end{array}$ \\
\hline pm2 & The company, the brand is a proof of quality; \\
\hline pm1 & $\begin{array}{l}\text { Paradoxically, a high quality product can be cheap (...) You just need to know it (...) have confidence or know the } \\
\text { manufacturer who produces it; }\end{array}$ \\
\hline
\end{tabular}

* a graphic mark of green clover with the inscription "natural product", the Polish manufacturer's quality label.

According to FG participants, the most controversial feature of high-quality foods was price and using it as a quality indicator is tricky. This is illustrated by the statements of the Belgian group: "price does not necessarily indicate quality" (bm) which shows that the meaning of price in assessing product quality is ambiguous for consumers. These conflicting opinions were also clearly expressed in the group of Polish men: "When we buy cheap it is almost certain that it will rarely happen that the product will be good, but if we pay a high price it is a lottery" (pm1). A woman in the Polish group put it this way: "if we are looking for something that is of better quality, then we want to believe that it is more expensive and will be tastier" (pw2). Consumers can therefore assume that the use of better-quality ingredients or more expensive methods of production results in a higher price for the final product. Whether (and how much) consumers are willing to pay for quality is difficult to assess and largely depends on the individual.

\subsection{Certification Labels as Product Quality Assurance}

Certification labels are a marketing communication tool used to identify a product and its quality. However, in the quantitative part of the survey $35 \%$ of Poles and $31 \%$ of Belgians admitted that they did not notice such indicators on the product's packaging. Respondents $(23 \%)$ had an ambivalent approach to quality labels on food products, claiming that they had no opinion on this subject. Less than half (44\%) of the total sample: $42 \%$ in the Polish group and $44 \%$ in the Belgian group declared that they take notice of certification labels displayed on food products. No statistically significant differences in the structure of responses among Polish and Belgian consumers were observed. 
In both groups positive declarations were correlated with age $(p<0.0001, v=0.2255$ and $p=0.0006, v=0.2134$ ). Among Poles, 60\% of respondents aged 46-55 and over 55 (59\%) paid attention to certification labels on food products. On the other hand, the highest percentage ( $48 \%$ ) of opposite answers were given by young respondents under the age of 25 . In the case of Belgian consumers, positive declarations were expressed mainly by people aged 36 to $45(59 \%)$ and 46 to $55(64 \%)$. As in the case of Poles, a significant percentage of people under 25 years of age (43\%) did not pay attention to that type of business to customer (B2C) information.

In the qualitative part of the study most interviewees admitted that they knew or saw at least some of the certificates presented on the mock-ups. During the discussions, participants from both countries used simplified terms, describing certification labels as signs, marks, symbols or simply as graphics. In the quoted statements of the respondents, these terms were left unchanged. Most often, the respondents were not able to determine their meaning or what the certification labels really certify, i.e., "I recognize the sign Znak jakości Q (Q Quality Mark) and Poznaj Dobra Żywność (Try Fine Food), these signs appeared somewhere, but I don't understand what they exactly mean" (pw2). It was also noted that a large number and diversity of food quality assurance certificates is confusing for consumers. Some participants of FGs were sceptical towards certification labels that prove to be a kind of greenwashing scheme. One of them said: "When I buy canned tuna, it is often written on it that fishing is dolphin-friendly, (...) but in reality tuna fishing practices are practically unmonitored and substantial numbers of dolphins and other sea animals are killed or harmed each year" (bw). Moreover, many opinions seriously questioned the trust that some of these certification labels deserve. However, they were made with reference to very specific examples, proving a higher level of knowledge about their meaning: "the Belgian product sign on Carrefour mayonnaise, it is a shame to advertise something as "buy it, because it is Belgian and it contains mainly fat" (bw).

Generally, it was observed that noticeability of certification labels was higher among women than men as well as among Belgian than Polish interviewees. Observations from both Belgian groups give the impression that knowledge about certification labels was deeper and the consumers' experience in Belgium is higher than in Poland.

Certification labels should reassure consumers about the quality and safety of what they buy and eat. However, the extent to which they guide consumer choices is rather limited. The results of quantitative research showed that for $36 \%$ of Poles and $40 \%$ of Belgians the presence of labels was "important" or "very important" when purchasing a product. The distribution of consumer opinions in both groups was similar and no statistically significant differences were found between them. Only in the Belgian group, the Cramer test confirmed a weak association $(p=0.0487, v=0.1549)$ between household income and the consumers' views. The presence of labels was "important" or "very important" for $47 \%$ of low-income respondents ( $<1.500$ EUR/month) and $44 \%$ of those with monthly earnings between 3.501 and 4.500 EUR.

The fact that the product won a competition or obtained an award was also not important for consumers when making food choices. Only $24 \%$ of study participants shared the opinion that such information is "important" or "very important". Overall awards and distinctions were more important for Polish (30\%) than Belgian (18\%) respondents. Among Belgians they were more important for respondents living in smaller (one- and two-person) households $(p=0.009, v=0.2173)$, with a secondary level of education $(p=0.0389, v=$ $0.1557)$ and those who assessed their financial situation as "very good" and "rather good" $(p=0.0452, v=0.1457)$.

Data collected during the FGs confirm the minor importance of certification labels in driving consumer choices while shopping. Nevertheless, when participants were asked if these labels ever prompted them to buy a food product, responses differed between groups by gender and nationality (Table 5 ). 
Table 5. Comments made by the FG participants on the importance of certification labels in making product choices when purchasing.

\begin{tabular}{|c|c|c|}
\hline Comments & Polish Focus Groups & Belgian Focus Groups \\
\hline \multirow{3}{*}{ Important } & \multicolumn{2}{|c|}{ Women } \\
\hline & $\begin{array}{l}\text { I pay attention to the } 0-3 \text { digital markings of the type of rearing } \\
(\ldots) \text { I don't buy either } 2 \text { or } 3, \text { but } 0(. . \text { ) the way hens are } \\
\text { reared and how they are fed is important to me (pw2) }\end{array}$ & $\begin{array}{l}\text { I buy products with distinctions, usually on cheeses, } \\
\text { but they usually come from France, although there are } \\
\text { also quite a few in Belgium, e.g., for Meritus meat, } \\
\text { 'Blanc Bleu Belge' (cattle breed) }\end{array}$ \\
\hline & $\begin{array}{l}\text { For me, the sign 'Teraz Polska' (Poland Now) matters, as I am a } \\
\text { local, and not only, patriot (pw1) }\end{array}$ & $\begin{array}{l}\text { I pay more and more attention to the Fair Trade, } \\
\text { Rainforest Alliance and Sustainable Fisheries } \\
\text { certificates, as environmental issues are becoming more } \\
\text { and more important to me. }\end{array}$ \\
\hline Not important & $\begin{array}{l}\text { None of the signs shown ever made me buy a food product } \\
\text { (pw1) } \\
\text { I'm not impressed by these signs, I don't pay attention' (pw2) }\end{array}$ & There are too many of these signs, similar to each other \\
\hline \multirow[t]{2}{*}{ Reasons } & $\begin{array}{l}\text { It is difficult to know if it is supported by some research or if the } \\
\text { company has not made a mark on itself (pw1) } \\
\text { Certificates and marks are a way to increase product sales (pw2) }\end{array}$ & $\begin{array}{l}\text { In general, I believe there are too many symbols and no } \\
\text { information who is awarding them }\end{array}$ \\
\hline & Men & \multirow{3}{*}{$\begin{array}{l}\text { If I have two dark chocolates to choose from, that are } \\
\text { difficult to compare with each other, I would choose the } \\
\text { one with the mark of Fair Trade } \\
\text { There is one sign that I pay attention to, it is a sign of } \\
\text { authentic Trappist beer. There are many beers that claim } \\
\text { to be original Trappist beers, but there only 8-9 really } \\
\text { are. They are made by monks in a monastery, according } \\
\text { to a special procedure (...) }\end{array}$} \\
\hline \multirow[t]{2}{*}{ Important } & $\begin{array}{l}\text { What matters to me is whether the product has won any } \\
\text { consumer awards (pm1) }\end{array}$ & \\
\hline & $\begin{array}{l}\text { The EU quality mark, that is to say the top shelf of the marks, } \\
\text { followed by a genuine verification system, for the rest of the } \\
\text { marks, this is not the case (pm2) }\end{array}$ & \\
\hline \multirow[t]{2}{*}{ Not important } & $\begin{array}{l}\text { I don't trust them, just because there are so many of them and } \\
\text { they don't guarantee me anything' (pm1) }\end{array}$ & \multirow{4}{*}{$\begin{array}{l}\text { I would like to believe that if a product has a quality } \\
\text { label that it is of good quality } \\
\text { Everyone knows the 'Best Frit' sign, but it has never } \\
\text { been a reason to go to this or that 'frituur' * for fries } \\
\text { I don't trust these signs, it's brainwashing, but you can } \\
\text { often see them on TV and probably the producers want } \\
\text { us to become familiar with them and associate them } \\
\text { with good quality } \\
\text { There is no sign that says 'we, an independent } \\
\text { organization that has nothing to do with the } \\
\text { manufacturer, certify that, for example, the production } \\
\text { of this product took place in a sustainable manner' }\end{array}$} \\
\hline & $\begin{array}{l}\text { This does not make shopping any easier, someone introduces too } \\
\text { many of these signs (pm2) }\end{array}$ & \\
\hline \multirow[t]{2}{*}{ Reasons } & $\begin{array}{l}\text { With a lot of time expenditure, it may be possible to decode what } \\
\text { all these characters mean, but another question is whether they } \\
\text { are actually verifiable (pm2) }\end{array}$ & \\
\hline & $\begin{array}{l}\text { For me, this is fashion, this is marketing, incorporated into the } \\
\text { price of the product' (pm1) }\end{array}$ & \\
\hline
\end{tabular}

* the specific Flemish name for typical Belgian bars with Belgian fries.

The dominant opinion among Polish women was that certification labels are not important when choosing food. The main reason for this belief is that the awarding or certification is unclear and there are obstacles to obtaining information about it. According to some interviewees certification labels on the packaging are simply an element of marketing that create additional product costs. When Polish women choose a certified food product, they are motivated by patriotism, concern for social welfare, environmental and animal welfare protection, or search for food products of better quality.

Participants of Polish male groups usually denied that certification marks are important to them when choosing food products. They expressed the most (out of all groups) doubts as to the method of granting certificates, as well as the procedures that must be followed by the producer in order to be authorized to use them. However, the in-depth discussion showed that certification can influence at least some of their purchasing decisions, i.e., "if I had to indicate one of the best products, then I would choose the one with most symbols" (pm2). Some of interviewees also indicated that it might be a good idea to develop one certification label that would be trustworthy and easily recognizable: "this work should begin on one or two certificates, although this is a utopia because there is such a big power that wants to operate on this market to realize its profits" (pm1). 
Among all the FGs, certification labels were of the greatest importance to Belgian women. This group was the only one to react enthusiastically and positively to the question of whether any of the certificates influenced the decision to buy a food product. Among the reasons for actively searching for information on the packaging, interviewees mentioned that it is related to the issues of sensitivity to animal welfare and environmental protection, home tradition or the search for high quality for certain product categories (e.g., beef, cheese). However, there were also reservations in this group regarding the huge number of labels on the market and the ambiguity about their use and meaning.

During the interviews with Belgian men, several statements were made that indicate a favourable approach to certification labels on the packaging of food products. These respondents showed great knowledge to take them into account when purchasing food, however, some of them questioned their validity. It was pointed out that even good knowledge and recognition of a particular certification label does not translate into its impact on shopping choices. Furthermore, labels can also cause bad publicity, i.e., a large number of certificates on a single product discourages instead of encouraging its purchase. Some respondents also indicated the need to introduce a single type of certification label that would provide consumers with concise information on various quality aspects of the product.

The qualitative part of the study found that $38 \%$ of its participants declared buying certified food or marked with other quality assurance symbols. In the case of Belgian consumers such a declaration came from $45 \%$ of them, while among the Polish group it was only $29 \%$. The percentage of consumers who clearly stated that they do not buy certified food was significantly higher in the Polish group (41\%) than in the Belgian one $(21 \%)$. A notable share of respondents (c.a. $30 \%$ in both groups) could not clearly answer this question. Affirmative declarations were correlated with age in both consumer groups. Among Polish respondents $(p=0.0048, v=0.1859)$ they were mainly expressed by people aged 45 years and above. In the case of Belgian consumers $(p=0.0030, v=0.1981)$, the majority of declarations were positive in all age groups except the youngest one (below 25 years).

FG participants repeatedly admitted that they buy food products with certification labels or marked with some distinction or award. The main reasons for buying them throughout all the groups were: confirmation of the particular production method, neutrality in terms of environmental impact, care for animal welfare, the guarantee of purchasing a product of a certain (high) quality and habits and traditions brought from home. Some of the statements confirming these observations are included in Table 5.

\section{Discussion}

The relationship between quality and the selection of food products has been analysed and discussed in previous studies based on several theoretical approaches [3,60,61]. Food quality is now recognized as one of the most important factors in food choices for $(65 \%$ of respondents), followed by product price (54\%), origin (34\%) and brand (15\%) [62]. Our research also focused on the perception of quality as a determinant of food products' choice. It turned out that quality was very important for Polish and Belgian consumers when choosing food, but they were not interested in quality per se. The respondents combined their perception of quality with different characteristics of the product, which guaranteed them a certain set of benefits, for example good taste and smell, beneficial effect on health, high quality of ingredients, awards, distinctions or medals that other products do not possess, etc. This phenomenon was previously explained by Lancaster who described product quality as a set of attributes defining product performance $[63,64]$ and developed in the "means-end approach" to consumer behaviour [65]. According to these theories, the consumer's perception of product quality comes down to assessing the compliance of the product's features (named "quality cues") with the consumer's needs and values. Our findings show that the surveyed consumers most often perceived high-quality food products through the prism of information about sensory features, the most fundamental 
quality indicators, and product sustainability (attributes related to wellbeing, known origin, with a low degree of processing and low environmental impact). Technological aspects and marketing features were seen as relatively less important and may for example satisfy the need for status. This confirms that from the consumer perspective food quality perception is a complex process, based on a subjective judgment of a set of desired product characteristics. Finally, consumers' perception of quality is an individual process related to their sociodemographic characteristics $[10,66,67]$ and situational factors like consumption situation, temporal context and environment $[68,69]$. Therefore, our study noted differences between respondents of different cultural backgrounds, as well as between consumers of different age groups, gender, education, income and households of different sizes.

Most of the study participants wanted to pay more for food products that conform to higher quality standards. This is supported by the results of several previous studies in which consumers were willing to pay a premium for high-quality food i.e., quality labelled products [70-72]. However, it also has been noted that agreeing to pay more for these products largely depends on the type of food (staple vs. luxury item), how it is produced (origin, recipe, technology), the purpose for who it will be used (own use, child, guests) and the prices consumers actually pay for it. In the opinion of consumers, the main barriers related to the purchase of high-quality food were the lack of affordability or the opinion that the signalled quality of the product does not really matter to them.

Consumers from both countries confirmed the availability of high-quality food products on the market. Among Polish respondents, the influence of the country-of-origin on the perceived food quality was more evident. Former studies suggest that countryof-origin affects consumer attitudes to a product (perceptions of its properties such as quality, reliability and price), through existing buyers' beliefs about the specificity of a given country or due to their loyalty to it [73-76]. Polish consumers indicated a positive attitude towards domestic food products also in another survey [77], which was mostly related to their belief in restricted use of pesticides, fertilisers or antibiotics or using better environmental practices. They also pointed to the problem of dual quality that is observed in their market (discriminatory practices consisting of selling different quality products in the western and eastern EU countries, but with identical brand and packaging). This issue is a part of the European Commission's ongoing work on how to identify and counter misleading commercial practices [78].

Certification labels are an important element of modern consumer policy, aimed at counteracting information asymmetry and protecting producers of food with special qualities [29,79-81]. Their aim is to inform consumers about higher quality and thus enable choice to be better in line with the preference [82-84]. Despite their guiding function, several studies report that respondents are not aware of the inner meaning of quality labels or misinterpret their sense $[85,86]$. The level of their familiarity and willingness to buy products with certificates varies greatly depending on the type of label, product, the socio-demographic factors of the consumer and situational context [40,56,87-89]

Findings from the present study reveal that respondents hold different levels of awareness related to quality labels. Their noticeability was higher among women and within Belgians rather than the Polish respondents. This may be due to the fact that, in general, women purchase food for households more often and therefore are more likely to notice certification labels when shopping. A highly developed food market in Belgium (with a long-established market economy) has driven manufacturers to introduce a larger number of food claims, certifications, messages and other information tools to differentiate their goods [90]. This probably leads to higher user experience and certificates' consciousness among Belgian consumers. Partly this may be a result of the state policy aimed at increasing the offer of certified products, the recognition of certificates among consumers and the demand for certified food. For example, in 2017 the Belgian Parliament adopted a resolution to promote fair trade and support the "Make Belgium a Fair Trade Country" campaign. Its goal was to increase the share of Belgians that have heard of fair trade to $95 \%$ in 2020 [91]. 
Results showed that most of the surveyed consumers were aware of certified labels but did not know exactly what they stand for and what institutions or organisations issued them. Earlier studies also suggest that respondents simply do not know them, do not understand their message in to the full extent or perceive a relatively low quality vs. price ratio for products with quality labels [86,92].

Our results also imply that the huge number of certification labels functioning in the food market overwhelms consumers, causes reluctance to familiarise them and creates a tendency to ignore them during decision-making. Overall too many certificates create resistance in consumers when they feel coerced to compare information and make choices $[93,94]$. An interesting idea, that comes from the studied men's groups in both countries, was to create a universal quality label that could prove the quality aspects and would apply to different products. However, the scope of certification covers many different things (used in relation to different areas, e.g., environmental protection, animal welfare, labour standards, supply chain, etc.) as well as different actors and their interests. For this reason, the development of a universal certification label and its implementation is rather complicated. Interestingly the European Economic and Social Committee (EESC) has recently called for exploring ways to harmonize voluntary eco-claims and create a sustainable labelling framework. These should cover the nutritional, climatic, environmental and social aspects of products $[95,96]$.

Nevertheless, some consumers consider quality labels as an important attribute that is able to drive their choices [13,79,86,90,97]. According to Eurobarometer data, for 33\% (2017) and 41\% (2020) of Europeans the specific label ensuring the quality of the product is a very important factor in the decision to buy a food product [87]. In our study a similar percentage of respondents admitted that they actively look for a quality certificate on the packaging when purchasing food. Certificates were important when shopping if their message was obvious and consistent with the respondent's personal beliefs on environmental protection, animal welfare, support for local economy and traditions etc. Most of the studied consumers perceived the superior value of products with certificates important for them and rejected those whose message is not clear or reliable. Therefore, it can be assumed that certification labels on food can serve as potential "filter" through which consumers form more general views on food product quality. In the case of sustainability labels, consumer knowledge and understanding of sustainability is a key prerequisite for increasing their importance and for their popularization $[56,98,99]$.

\section{Conclusions}

The results of this study imply that due to the fact that certification labels refer to different areas of quality, including the food product's environmental impact, animal welfare, climate change, human rights, labour standards etc. consumers tend to perceive them with caution. Sometimes certificates are ignored because potential buyers do not understand what they mean, are not sure about their credibility or have doubts about the certification authority. In general, women show greater awareness and better knowledge of quality certificates than men and Belgian consumers have a deeper knowledge and are have a more positive (favourable) attitude towards certification labels than Poles.

Price was pointed out by interviewed FG participants as the most controversial feature of high-quality foods influencing consumer perception of quality. The prices that people living in different countries are willing to pay for labelled high-quality foods vary and can be assessed with the use of specific Willingness to Buy (WTB) and (Readiness to Pay (RTP) indicators. They are highly dependent on the financial situation of consumers, incl. per capita income level. Therefore, it is clear that economic factors, such as food affordability should be taken into consideration by policymakers and managers when developing quality assurance schemes in attempts to introduce new labels pointing at the product's sustainability.

Despite the fact that the obtained results show that consumers pay more attention to sensory attributes than certification labels these tools can have an important role in deliv- 
ering a message on the quality and sustainability of products. The analysis of qualitative data demonstrated that labels that are consistent with the respondent's personal beliefs have a direct impact on quality perception and thus food choice. Consumers' understanding of food quality importance is key to adopting sustainable consumption patterns and drives consumer choices towards healthier, more sustainable options. Therefore, there is a need for public institutions to expand and intensify promotion and communication efforts to help consumers understand the need to shift towards sustainability and to increase credibility and the role of certification labels in promoting food quality, sustainability and market transparency.

The Farm to Fork (F2F) Strategy marks the beginning of a process aiming to fundamentally change the way food is provided to EU consumers. Within the F2F Strategy, the European Commission announced several measures for labelling and that it will "examine ways to harmonize voluntary green claims" and propose a sustainable food labelling framework that covers the nutritional, climate, environmental and social aspects of food products. F2F objectives will need to be converted into legislative proposals, and the European Parliament and Member States will shape and amend these proposals as part of the EU legislative process. This multistep legislative development will take several years to complete and therefore research on this quality and sustainability-linked labelling is very much needed in the framework of future sustainability of food chains, incl. consumer behaviour.

The results of the present study should be regarded in the context of their limitations. Firstly, the quantitative research used the non-probability purposive sampling method of data collection, that regardless of the significant advantages, can introduce some bias. Our respondents were overrepresented in some socio-demographic characteristics (i.e., higher education level and higher annual household income). It is also possible that respondents who are more interested in the topic are therefore more willing to participate in the study. They may have also been influenced by social attitudes during face-to-face interviews and respond in a socially acceptable way. Finally, the present study focused on the influence of certification labels in general on perceived food product quality; however, some of them may be more effective than others in facilitating the communication of information to consumers.

Author Contributions: Conceptualization J.K., K.R. and A.P.; methodology, K.R., A.P.; data extraction and synthesis J.K., A.P.; writing-original J.K., K.R and E.H., writing-review and editing E.H., K.R., J.K. and A.T.-K.; and supervision E.H., K.R., J.K. All authors have read and agreed to the published version of the manuscript.

Funding: This research received no external funding.

Institutional Review Board Statement: The study was conducted according to the guidelines of the Declaration of Helsinki, and approved by the Board of Faculty of Human Nutrition and Consumer Sciences Warsaw University of Life Sciences-SGGW (WULS-SGGW) Resolution (protocol 145 dated 25.09.2019).

Informed Consent Statement: Informed consent was obtained from all subjects involved in the study.

Data Availability Statement: Data are not publicly available, though the data may be made available on request from the corresponding author.

Conflicts of Interest: The authors declare no conflict of interest. 


\section{Appendix A}

Table A1. Quantitative research questions analysed in the article.

Question
Q1. Do you take into account the quality of food products when
shopping?

Single choice question

$\quad$ Answers/Options
Definitely no
Rather no
No opinion
Rather yes
Definitely yes
1-definitely no
2-rather no
3-no opinion
4-rather yes
5-definitely yes
1-definitely no
2-rather no
3-no opinion
4-rather yes
5-definitely yes
Very low
Low
Average
High
Very high
Good taste and smell
Attractive appearance
I am not able to tell
Special production method or with use of special technology
Special recipe
High quality of ingredients
Beneficial effect on health
Esthetical/attractive packaging
Ingredients of known and controlled origin
Indication, symbol or certificate on the packaging that other
products do not have
Sales in reputable places
Minimal level of processing
High price
Awards, distinctions, medals obtained
No/very low amount of additives, e.g., colorants,
preservatives, enhancers
Extensive advertising and promotion
Ethical production
Yes
No
1-mortant
-

Q5. In your opinion, which features distinguish food products of high quality?

Single-response matrix question with a five-level Likert-type scale: 1-strongly disagree/2-rather disagree/3-neither yes nor no/4-rather agree/5-strongly agree

Q6. Do you take notice of the quality certification/confirmation marks on food products?

Single choice question

Q7. How important are: Indication, symbol or certificate on the packaging that other products do not have in your choice of food products?

Single-response matrix question with a five-level ascending scale

Q8. How important are: Awards, distinctions, medals obtained in your choice of food products?Single-response matrix question with a five-level ascending scale

Q9. Do you buy food products certified or marked with a specific quality certification symbol?

Single choice question
Definitely no

Rather yes

Definitely yes

-definitely no

4-rather yes

5-definitely ye

definitely no

-rather no

5 -definitely

Very low

Average

High

Attractive appearance

Special production method or with use of special technology

recipe

Esthetical/attractive packaging

Indication, symbol or certificate on the packaging that other products do not have

Sales in reputable places

processing

High price

No/very low amount of additives, e.g., colorants,

preservatives, enhancers

Ethical production

I am not able to tell

1 -least important 
Table A2. Qualitative research questions analysed in the article.

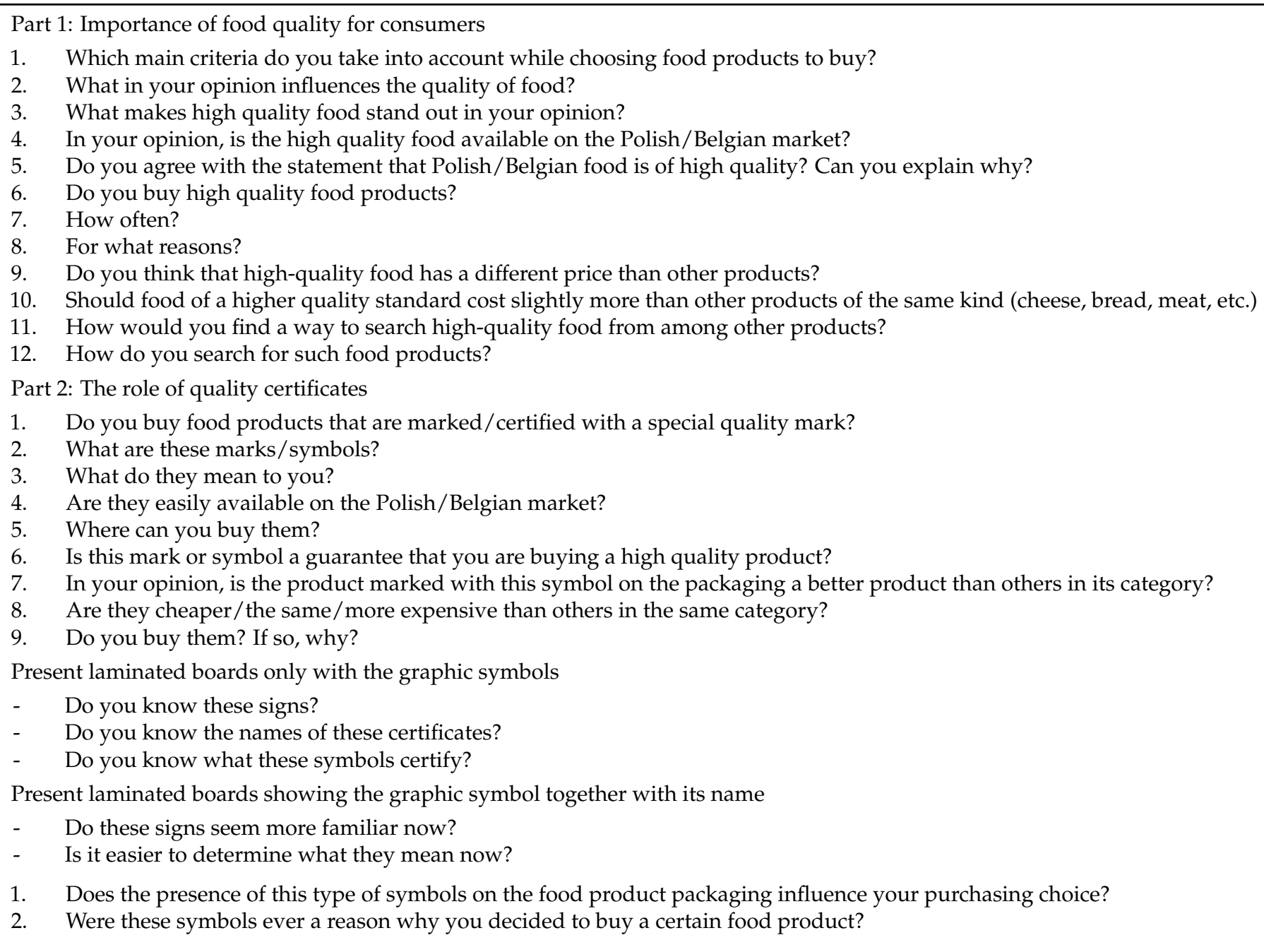

\section{References}

1. Kołożyn-Krajewska, D. Jakość i Bezpieczeństwo Żywności w Sprzedaży Bezpośredniej. In Opinie i Ekspertyzy OE-231; Biuro Analiz i Dokumentacji: Warsaw, Poland, 2015.

2. Grunert, K.G. Food Quality and Safety: Consumer Perception and Demand. Eur. Rev. Agric. Econ. 2005, 32, 369-391. [CrossRef]

3. Brunsø, K.; Fjord, T.A.; Grunert, K.G. Consumers' Food Choice and Quality Perception; The Aarhus School of Business: Aarhus, Denmark, 2002.

4. Brunori, G. Local food and alternative food networks: A communication perspective. Anthr. Food. 2007, 2. [CrossRef]

5. Grunert, K.G. Current issues in the understanding of consumer food choice. Trends Food Sci. Technol. 2002, 13, 275-285. [CrossRef]

6. Chance, Z.; Gorlin, M.; Dhar, R. Why Choosing Healthy Foods is Hard, and How to Help: Presenting the 4Ps Framework for Behavior Change. Cust. Needs Solut. 2014, 1, 253-262. [CrossRef]

7. Jeżewska-Zychowicz, M.; Jeznach, M. Konsumencka Percepcja Jakości Żywności o Zmodyfikowanym Składzie. Probl. Hig. Epidemiol. 2014, 95, 692-695.

8. Cyrek, P.; Grzybek, M.; Makarski, S. Kreowanie Jakości Handlowej Artykułów Żywnościowych—Creation of commercial Quality of Food Products; Wydawnictwo Uniwersytetu Rzeszowskiego: Rzeszów, Poland, 2016.

9. Sadílek, T. Perception of Food Quality by Czech Consumers: Literature Review. Eur. Res. Stud. J. 2019, $22,57-67$.

10. Petrescu, D.C.; Vermeir, I.; Petrescu-Mag, R.M. Consumer Understanding of Food Quality, Healthiness, and Environmental Impact: A Cross-National Perspective. Int. J. Environ. Res. Public Health 2019, 17, 169. [CrossRef]

11. Gellynck, X.; Kühne, B. Future Role of Quality Assurance Schemes in the EU Agribusiness Sector; Agriculture Sciences: Vilnius, Lithuania, 2007; Volume 14, pp. 165-170.

12. Halicka, E. Postawy i Zachowania Nabywcze Kobiet Wobec Znakowania Żywności Symbolami Dobrowolnych Certyfikatów Jakości. Zesz. Nauk. SGGW Ekon. Organ. Gospod. Żywn. 2016, 115, 141-149. [CrossRef] 
13. Velčovská, Š.; Del Chiappa, G. The Food Quality Labels: Awareness and Willingness to Pay in the Context of the Czech Republic. Acta Univ. Agric. Silvic. Mendel. Brun. 2015, 63, 647-658. [CrossRef]

14. Regulation (EU) No.1169/2011 of the European Parliament and of the Council of 25 October 2011 on the Provision of Food Information to Consumers, amending Regulations (EC) No. 1924/2006 and (EC) No. 1925/2006 of the European Parliament and of the Council, and repealing Commission Directive 87/250/EEC, Council Directive 90/496/EEC, Commission Directive 1999/10/EC, Directive 2000/13/EC of the European Parliament and of the Council, Commission Directives 2002/67/EC and 2008/5/EC and Commission Regulation (EC) No. 608/2004 Text with EEA relevance. Off. J. Eur. Un. 2011, 304, 18-63.

15. Mori, M.; Roest, H.-J. Farming, Q fever and public health: Agricultural practices and beyond. Arch. Public Health 2018, 76, 2. [CrossRef] [PubMed]

16. The One Health Initiative. Available online: https://onehealthinitiative.com/ (accessed on 18 December 2020).

17. MacKenzie, J.S.; Jeggo, M. The One Health Approach-Why Is It So Important? Trop. Med. Infect. Dis. 2019, 4, 88. [CrossRef] [PubMed]

18. Gebreyes, W.A.; Dupouy-Camet, J.; Newport, M.J.; Oliveira, C.J.B.; Schlesinger, L.S.; Saif, Y.M.; Kariuki, S.; Saif, L.J.; Saville, W.; Wittum, T.; et al. The Global One Health Paradigm: Challenges and Opportunities for Tackling Infectious Diseases at the Human, Animal, and Environment Interface in Low-Resource Settings. PLoS Negl. Trop. Dis. 2014, 8, e3257. [CrossRef] [PubMed]

19. European Commission. Quality Schemes Explained. Available online: https://ec.europa.eu/info/food-farming-fisheries/foodsafety-and-quality/certification/quality-labels/quality-schemes-explained_en (accessed on 18 December 2020).

20. L'Europe Signe les Produits de ses Terroirs. Available online: https:/ / www.pdopgi.eu/ (accessed on 18 December 2020).

21. Food Labelling, 5th ed.; Joint FAO/WHO Codex Alimentarius Commission; WHO: Geneva, Switzerland; FAO: Rome, Italy, 2007.

22. Nowak, K. Etykietowanie Żywności w Świetle Wymagań Prawnych-Praktyczna Interpretacja. Mięs. Technol. 2020, 3, 92-98. Available online: https://spozywczetechnologie.pl/miesne-technologie/technologie-produkcji/549/etykietowanie-zywnosciw-swietle-wymagan-prawnych-praktyczna-interpretacja (accessed on 15 November 2020).

23. Kolodinsky, J. Persistence of Health Labeling Information Asymmetry in the United States. J. Macromark. 2012, 32, 193-207. [CrossRef]

24. Verbeke, W. Agriculture and the food industry in the information age. Eur. Rev. Agric. Econ. 2005, 32, 347-368. [CrossRef]

25. Azman, N.; Sahak, S.Z. Nutritional Label and Consumer Buying Decision: A Preliminary Review. Procedia Soc. Behav. Sci. 2014, 130, 490-498. [CrossRef]

26. Bandara, B.; De Silva, D.; Maduwanthi, B.; Warunasinghe, W. Impact of Food Labeling Information on Consumer Purchasing Decision: With Special Reference to Faculty of Agricultural Sciences. Procedia Food Sci. 2016, 6, 309-313. [CrossRef]

27. Kumar, N.; Kapoor, S. Do labels influence purchase decisions of food products? Study of young consumers of an emerging market. Br. Food J. 2017, 119, 218-229. [CrossRef]

28. Sirieix, L.; Delanchy, M.; Remaud, H.; Zepeda, L.; Gurviez, P. Consumers' Perceptions of Individual and Combined Sustainable Food Labels: A UK Pilot Investigation: Consumers' Perceptions of Sustainable Food Labels. Int. J. Consum. Stud. 2013, 37, 143-151. [CrossRef]

29. Tonkin, E.; Wilson, A.; Coveney, J.; Webb, T.; Meyer, S.B. Trust in and through labelling-A systematic review and critique. Br. Food J. 2015, 117, 318-338. [CrossRef]

30. Gussow, J.D. Reflections on Nutritional Health and the Environment: The Journey to Sustainability. J. Hunger. Environ. Nutr. 2006, 1, 3-25. [CrossRef]

31. World Health Organization. Sustainable Healthy Diets: Guiding Principles; FAO: Rome, Italy, 2019.

32. WWF-UK. Eating for 2 Degrees_-New and Updated Livewell Plates; The World Wildlife Fund (WWF): Godalming, UK, 2017.

33. The Sustain Guide to Good Food: How to Help Make Our Food and Farming System Fit. for the Future; Sustain: The Alliance for Better Food and Farming: London, UK, 2013.

34. Steingolt, M.; Picciola, M.; Wilson, R. Consumer Health Claims 3.0: The Next Generation of Mindful Food Consumption; L.E.K: Boston, MA, USA, 2018; pp. 1-6.

35. Neale, A. Zrównoważona Konsumpcja. Źródła Koncepcji i Jej Zastosowanie. In PRACE GEOGRAFICZNE, Zeszyt 141; Instytut Geografii i Gospodarki Przestrzennej UJ: Cracow, Poland; pp. 141-158. Available online: https://www.ejournals.eu/PraceGeograficzne/Tom-2015/Numer-141/art/6011 (accessed on 25 October 2020).

36. Saeed, F.; Grunert, K.G. Expected and experienced quality as predictors of intention to purchase four new processed beef products. Br. Food J. 2014, 116, 451-471. [CrossRef]

37. Jahn, G.; Schramm, M.; Spiller, A. The Reliability of Certification: Quality Labels as a Consumer Policy Tool. J. Consum. Policy 2005, 28, 53-73. [CrossRef]

38. Dekhili, S.; Achabou, M.A. Eco-labelling brand strategy: Independent Certification versus Self-Declaration. Eur. Bus. Rev. 2014, 26, 305-329. [CrossRef]

39. Chen, Y.; Chang, C. Enhance Green Purchase Intentions: The Roles of Green Perceived Value, Green Perceived Risk, and Green Trust. Manag. Decis. 2012, 50, 502-520. [CrossRef]

40. Consumer Market. Study on the Functioning of Voluntary Food Labelling Schemes for Consumers in the European Union EAHC/FWC/2012 86 04; Ipsos and London Economics Consortium: London, UK, 2013; pp. 1-448.

41. Ecolabel Index. Who's deciding what's green? Available online: http:/ / www.ecolabelindex.com/ (accessed on 13 August 2019). 
42. Sørensen, H.S.; Holm, L.; Møgelvang-Hansen, P.; Barratt, D.; Qvistgaard, F.; Smith, V. Consumer Understanding of Food Labels: Toward a Generic Tool for Identifying the Average Consumer: Report from a Danish Exploration. Int. Rev. Retail. Distrib. Consum. Res. 2013, 23, 291-304. [CrossRef]

43. Kalnikaite, V.; Bird, J.; Rogers, Y. Decision-making in the aisles: Informing, overwhelming or nudging supermarket shoppers? Pers. Ubiquitous Comput. 2013, 17, 1247-1259. [CrossRef]

44. Atkinson, L.; Rosenthal, S. Signaling the Green Sell: The Influence of Eco-Label Source, Argument Specificity, and Product Involvement on Consumer Trust. J. Advert. 2014, 43, 33-45. [CrossRef]

45. Kaczorowska, J.; Rejman, K.; Halicka, E.; Szczebyło, A.; Górska-Warsewicz, H. Impact of Food Sustainability Labels on the Perceived Product Value and Price Expectations of Urban Consumers. Sustainability 2019, 11, 7240. [CrossRef]

46. Rupprecht, C.D.D.; Fujiyoshi, L.; McGreevy, S.R.; Tayasu, I. Trust me? Consumer trust in expert information on food product labels. Food Chem. Toxicol. 2020, 137, 111170. [CrossRef] [PubMed]

47. Eurostat, the statistical office of the European Union. How Much are Households Spending on Food? Available online: https:/ / ec.europa.eu/eurostat/web/products-eurostat-news/- /DDN-20181204-1 (accessed on 18 December 2020).

48. Statista. The Statistics Portal. Leading Retail Chains in Poland in 2019, by Revenues. Available online: https://www.statista. $\mathrm{com} /$ statistics / 1080372/poland-top-retail-chains-by-revenues/ (accessed on 18 December 2020).

49. Internal Market. in 2019; Statistics Poland: Warsaw, Poland, 2020.

50. Grocery Retail. Market. in Poland 2019. Market. Analysis and Development Forecasts for 2019-2024; PMR Ltd.: Krakow, Poland, 2020; Available online: https:/ / mypmr.pro/products/grocery-retail-market-in-poland-2019 (accessed on 18 December 2020).

51. Market Research.com. Food and Grocery Retail. in Belgium; MTLN16319055; MarketLine: London, UK, 2020; 38p.

52. Retailing in Belgium; Euromonitor International: London, UK, 2020.

53. Retailing in Poland; Euromonitor International: London, UK, 2020.

54. Nyumba, T.O.; Wilson, K.; Derrick, C.J.; Mukherjee, N. The use of focus group discussion methodology: Insights from two decades of application in conservation. Methods Ecol. Evol. 2018, 9, 20-32. [CrossRef]

55. Maison, D. Qualitative Marketing Research: Understanding Consumer Behaviour, 1st ed.; Routledge: Abingdon, UK, 2018. [CrossRef]

56. Grunert, K.G.; Hieke, S.; Wills, J. Sustainability labels on food products: Consumer motivation, understanding and use. Food Policy 2014, 44, 177-189. [CrossRef]

57. Leach, A.M.; Emery, K.A.; Gephart, J.; Davis, K.F.; Erisman, J.W.; Emery, K.A.; Pace, M.L.; D’Odorico, P.; Carr, J.; Noll, L.C.; et al. Environmental impact food labels combining carbon, nitrogen, and water footprints. Food Policy 2016, 61, 213-223. [CrossRef]

58. Rejman, K.; Kaczorowska, J.; Halicka, E.; Laskowski, W. Do Europeans consider sustainability when making food choices? A survey of Polish city-dwellers. Public Health Nutr. 2019, 22, 1-10. [CrossRef]

59. Dubes, R.C.; Jain, A.K. Clustering Methodologies in Exploratory Data Analysis. In Advances in Computers; Yovits, M.C., Ed.; Elsevier: Amsterdam, The Netherlands, 1980; Volume 19, pp. 113-228. [CrossRef]

60. Shepherd, R. Factors Influencing Food Preferences and Choice. In Handbook of the Psychophysiology of Human Eating; Wiley: Hoboken, NJ, USA, 1989; Volume 3.

61. Steenkamp, J.-B.E. Conceptual model of the quality perception process. J. Bus. Res. 1990, 21, 309-333. [CrossRef]

62. TNS Opinion \& Social. Europeans' Attitudes towards Food Security, Food Quality and the Countryside. In Special Eurobarometer; Wave EB77.2 389; European Commission: Brussels, Belgium, 2012.

63. Ironmonger, D.S.; Lancaster, K. Consumer Demand: A New Approach. Economica 1975, 42, 212. [CrossRef]

64. Caswell, J.A.; Mojduszka, E.M. Using Informational Labeling to Influence the Market for Quality in Food Products. Am. J. Agric. Econ. 1996, 78, 1248-1253. [CrossRef]

65. Reynolds, T.J.; Olson, J.C. (Eds.) Understanding Consumer Decision Making: The Means-End Approach to Marketing and Advertising Strategy; Lawrence Erlbaum Associates, Inc.: Mahwah, NJ, USA, 2001.

66. Onwezen, M.; Reinders, M.J.; Van Der Lans, I.A.; Sijtsema, S.J.; Jasiulewicz, A.; Guardia, M.D.; Guerrero, L. A cross-national consumer segmentation based on food benefits: The link with consumption situations and food perceptions. Food Qual. Preference 2012, 24, 276-286. [CrossRef]

67. Brečić, R.; Mesić, Ž.; Cerjak, M. Importance of intrinsic and extrinsic quality food characteristics by different consumer segments. Br. Food J. 2017, 119, 845-862. [CrossRef]

68. Fernqvist, F.; Ekelund, L. Credence and the effect on consumer liking of food-A review. Food Qual. Prefer. 2014, 32, 340-353. [CrossRef]

69. Köster, E. Diversity in the determinants of food choice: A psychological perspective. Food Qual. Prefer. 2009, 20, 70-82. [CrossRef]

70. Krystallis, A.; Chryssohoidis, G. Consumers' Willingness to Pay for Organic Food: Factors That Affect It and Variation per Organic Product Type. Br. Food J. 2005, 107, 320-343. [CrossRef]

71. Janssen, M.; Hamm, U. Product labelling in the market for organic food: Consumer preferences and willingness-to-pay for different organic certification logos. Food Qual. Prefer. 2012, 25, 9-22. [CrossRef]

72. Pérez, L.P.Y.; Gracia, A.; Hurlé, J.B. Not Seeing the Forest for the Trees: The Impact of Multiple Labelling on Consumer Choices for Olive Oil. Foods 2020, 9, 186. [CrossRef] [PubMed]

73. Verlegh, P.W.; Steenkamp, J.-B.E. A review and meta-analysis of country-of-origin research. J. Econ. Psychol. 1999, 20, 521-546. [CrossRef] 
74. Laroche, M.; Papadopoulos, N.; Heslop, L.A.; Mourali, M. The influence of country image structure on consumer evaluations of foreign products. Int. Mark. Rev. 2005, 22, 96-115. [CrossRef]

75. Anić, I.D. Attitudes and Purchasing Behavior of Consumers in Domestic and Foreign Food Retailers in Croatia. Zb. Rad. Ekon. Fak. Rijeci 2010, 28, 113-133.

76. Yang, S.-H.; Hu, W.; Mupandawana, M.; Liu, Y. Consumer Willingness to Pay for Fair Trade Coffee: A Chinese Case Study. J. Agric. Appl. Econ. 2012, 44, 21-34. [CrossRef]

77. Bryła, P. The role of appeals to tradition in origin food marketing. A survey among Polish consumers. Appetite 2015, 91, 302-310. [CrossRef]

78. BEUC The European Consumer Organisation. Dual Product Quality Across Europe: State-of-Play and the Way Forward. Providing All of Europe's Consumers with Products of the Fair Quality They Expect; BEUC-X-2018-031; BEUC: Brussels, Belgium, 2018 ; pp. 1-15.

79. Grunert, K.G.; Aachmann, K. Consumer reactions to the use of EU quality labels on food products: A review of the literature. Food Control. 2016, 59, 178-187. [CrossRef]

80. Albuquerque, T.G.; Oliveira, M.B.P.; Costa, H.S. 25 Years of European Union (EU) Quality Schemes for Agricultural Products and Foodstuffs across EU Member States. J. Sci. Food Agric. 2018, 98, 2475-2489. [CrossRef] [PubMed]

81. TNS Political \& Social. Europeans, Agriculture and the CAP. In Special Eurobarometer; EBS 474; European Commission: Brussels, Belgium, 2017.

82. Verbeke, W. Food Quality Policies and Consumer Interests in the EU. In Consumer Attitudes to Food Quality Products; Klopčič, M., Kuipers, A., Hocquette, J.-F., Eds.; Wageningen Academic Publishers: Wageningen, The Netherlands, 2013; pp. 13-22. [CrossRef]

83. Żakowska-Biemans, S.; Gutkowska, K. Atrybuty Zaufania Dotyczacce Jakości Jako Czynnik Wpływający Na Decyzje Nabywcze Konsumentów Żywności. Zesz. Nauk. SGGW Ekon. Organ. Gospod. Żywn. 2018, 121, 115-130. [CrossRef]

84. Wang, J.; Tao, J.; Chu, M. Behind the label: Chinese consumers' trust in food certification and the effect of perceived quality on purchase intention. Food Control. 2020, 108, 106825. [CrossRef]

85. Tonkin, E.; Meyer, S.B.; Coveney, J.; Webb, T.; Wilson, A. The process of making trust related judgements through interaction with food labelling. Food Policy 2016, 63, 1-11. [CrossRef]

86. Pinna, M.; Del Chiappa, G.; Atzeni, M. Do Consumers Really Care about Food Quality Labels? Qual. Access Success 2017, 18, 135-140.

87. Kantar. Europeans, Agriculture and the CAP. In Special Eurobarometer; Wave EB93.2 504; European Commission: Brussels, Belgium, 2020; p. 301.

88. Rodrigues, D.B.; Dalmarco, D.D.A.S.; Aoqui, C.; Marinho, B.D.L. The meaning of the organic certification label for the consumer: A cluster analysis. Rev. Gest. 2016, 23, 316-325. [CrossRef]

89. Annunziata, A.; Angela, M.; Vecchio, R. Effectiveness of sustainability labels in guiding food choices: Analysis of visibility and understanding among young adults. Sustain. Prod. Consum. 2019, 17, 108-115. [CrossRef]

90. Verbeke, W.; Pieniak, Z.; Guerrero, L.; Hersleth, M. Consumers' Awareness and Attitudinal Determinants of European Union Quality Label Use on Traditional Foods. Bio Based Appl. Econ. 2012, 213-229. [CrossRef]

91. Kingdom of Belgium. Belgium Well on the Way to Becoming Fair Trade Country. Available online: https:/ / diplomatie.belgium. be/en/newsroom/news/2017/fair_trade_week (accessed on 15 November 2020).

92. Velčovská, Š.; Hadro, D. Generation Y Perceptions and Expectations of Food Quality Labels in the Czech Republic and Poland. Acta Univ. Agric. Silvic. Mendel. Brun. 2018, 66, 325-334. [CrossRef]

93. Gracia, A.; De-Magistris, T. Consumer preferences for food labeling: What ranks first? Food Control. 2016, 61, 39-46. [CrossRef]

94. Fenko, A.; Kersten, L.; Bialkova, S. Overcoming consumer scepticism toward food labels: The role of multisensory experience. Food Qual. Prefer. 2016, 48, 81-92. [CrossRef]

95. EESC European Economic and Social Committee. Promoting Healthy and Sustainable Diets in the EU (Own-Initiative Opinion); Opinion NAT/755-EESC-2018-04568; European Commission: Brussels, Belgium, 2019; pp. 1-12.

96. European Commission. Dual Food Quality: Questions and Answers. Available online: https://ec.europa.eu/commission/ presscorner/detail/en/QANDA_19_3333 (accessed on 18 November 2020).

97. Resano, H.; Sanjuán, A.I.; Albisu, L.M. Consumers' response to the EU Quality policy allowing for heterogeneous preferences. Food Policy 2012, 37, 355-365. [CrossRef]

98. Kijek, T. Modelling of Eco-innovation Diffusion: The EU Eco-label. Comp. Econ. Res. Cent. East. Eur. 2015, 18, 65-79. [CrossRef]

99. Peschel, A.O.; Grebitus, C.; Steiner, B.; Veeman, M. How does consumer knowledge affect environmentally sustainable choices? Evidence from a cross-country latent class analysis of food labels. Appetite 2016, 106, 78-91. [CrossRef] 